Check for updates

The BMJ

Cite this as: $B M J$ 2021;373:n1040 http://dx.doi.org/10.1136/bmj.n1040 Published: 21 April 2021

\title{
Covid-19: Government faces legal action over $£ 102 m$ contract for FFP3 masks
}

\section{Clare Dyer}

The UK government is facing legal action over a $€ 102.6 \mathrm{~m}$ ( $€ 119 \mathrm{~m}$; \$143m) contract for $\mathrm{FFP}_{3}$ respirators to be worn by healthcare staff treating covid-19 patients, which was granted without competition last July.

The claim is the latest by the Good Law Project to challenge the lawfulness of government action in procuring personal protective equipment (PPE) during the covid-19 pandemic.

The non-profit campaign group has written a letter before action to lawyers for the Department of Health and Social Care for England, asking them to disclose key documents behind the decision to award the contract for Meixin respirators to Pharmaceuticals Direct.

The contract, which was awarded without competitive tender, was not published until 29 March, although the prime minister, Boris Johnson, had told parliament in February that details of all covid-19 contracts were now "on the record.” The High Court has already ruled, in an earlier case brought by the Good Law Project, that England's health secretary, Matt Hancock, acted unlawfully in failing to publish details of covid-19 contracts. ${ }^{1}$

The group argues that the reason given by the government for bypassing competition in awarding the contract-namely. the urgency created by the pandemic-no longer applied by July. It also alleges apparent bias or breach of the government's equal treatment obligations in awarding the contract without competition to a company represented by "a well connected figure within the Conservative Party."

The company representative named in the contract is Samir Jassal, a former Conservative councillor who has twice stood as a parliamentary candidate for the party and has campaigned with the prime minister. He is standing as a candidate for councillor again in May's local government elections and has donated $£ 4000$ to the party.

Jassal's LinkedIn profile states that he has previously worked with Priti Patel, who is now home secretary. Jassal told the BBC that he was a consultant to Pharmaceuticals Direct.

\section{"VIP" contracts}

The Good Law Project has raised concerns about the extent to which lucrative contracts have been awarded to companies with Conservative Party links. At the height of the pandemic, amid a worldwide shortage of PPE, the government set up a high priority or "VIP" lane for leads coming from government officials, ministers' offices, MPs, and members of the House of Lords.
The campaign group has asked government lawyers whether the Pharmaceuticals Direct contract was allocated to the high priority lane. The National Audit Office, the government spending watchdog, found that one in 10 suppliers that came through the high priority lane secured a contract, compared with only one in 100 that used the ordinary route. ${ }^{2}$

A spokesperson for the Department of Health and Social Care said in a statement, "The first duty of any government in a national crisis is to protect the public and save lives, and to do that when confronted with this global pandemic we had to rapidly procure and produce PPE. Production and procurement involved setting up a new logistics network from scratch and expanding our PPE supply chain from 226 NHS trusts in England to more than 58 ooo different settings, all of which was taking place at a time when global demand was greater than ever before.

"All PPE procurement went through the same assurance process and, in conjunction with those checks, due diligence is carried out on every contract with ministers having no involvement in deciding who is awarded them."

Dyer C. Covid-19: Hancock's failure to publish contracts was unlawful. BMJ 2021;372:n511. doi: 10.1136/bmj.n511 pmid: 33608255

2 lacobucci G. Covid-19: Government has spent billions on contracts with little transparency, watchdog says. BM/2020;371:m4474. doi: 10.1136/bmj.m4474 pmid: 33208349

This article is made freely available for use in accordance with BMJ's website terms and conditions for the duration of the covid-19 pandemic or until otherwise determined by BMJ. You may use, download and print the article for any lawful, non-commercial purpose (including text and data mining) provided that all copyright notices and trade marks are retained. 